\title{
POSTERIOR VERTEBRAL COLUMN RESECTION IN MULTIPLE LEVELS IN CHILDREN WITH VERTEBRAL TUBERCULOSIS
}

\author{
VERTEBRECTOMIA POSTERIOR MULTINÍVEL EM CRIANÇAS COM \\ TUBERCULOSE VERTEBRAL
}

\author{
VERTEBRECTOMÍA POSTERIOR EN MÚLTIPLES NIVELES EN NIÑOS CON \\ TUBERCULOSIS VERTEBRAL
}

\author{
Alderico Girão Campos de Barros, ${ }^{1}$ luis Eduardo Carelli Teixeira da Silva, ${ }^{1}$ Marcelo Glauber da Silva Pereira, ${ }^{1}$ Andre luiz loyelo Barcellos, ${ }^{1}$ \\ LUCAS Rocha CAVALCANTI \\ 1. Instituto Nacional de Traumatologia e Ortopedia, Rio de Janeiro, RJ, Brasil.
}

\begin{abstract}
Objective: To evaluate the clinical and radiological results of posterior vertebral column resection in the treatment of kyphosis due to vertebral tuberculosis in children under 9 years of age with neurological deficit. Methods: Retrospective study of a series of 5 cases, 4 females and 1 male, mean age of 4.7 years at the time of surgery, with spinal tuberculosis and mean kyphosis of 89 degrees. Results: All patients underwent surgical treatment with PVCR in multiple levels, with a mean number of 3.6 resected vertebrae, mean surgical time of 359 minutes, mean postoperative stay of 21.2 days. The mean follow-up was 29 months. The mean kyphosis correction was $62.6 \%$. Before surgery, all patients had signs of spinal cord injury, one of which did not present a deficit of strength or sensibility (ASIA E), but there were pyramidal signs and a history of falls. The other 4 had some degree of sensory-motor dysfunction, with ASIA score varying from A to D. Postoperative complications included two dehiscences of suture, one pneumothorax and one pneumonia, all with favorable evolution. Four patients progressed with neurological improvement and one of them had persistence of the neurological deficit until the last follow-up. Conclusions: Multiple-level PVCR has proven to be a safe and effective option for the treatment of kyphotic deformity in spinal tuberculosis in children with neurological deficit. Level of evidence IV; Case Series.
\end{abstract}

Keywords: Tuberculosis, Spinal; Spinal Cord Compression; Neurologic Dysfunction.

\section{RESUMO}

Objetivo: Avaliação dos resultados clínicos e radiológicos da vertebrectomia posterior multinível no tratamento da cifose por tuberculose vertebral em crianças menores de 9 anos apresentando déficit neurológico. Métodos: Estudo retrospectivo de uma série de 5 casos, sendo 4 do sexo feminino e 1 do sexo masculino, média de idade de 4,7 anos na época da cirurgia, portadoras de tuberculose vertebral múltiplos níveis, com média de cifose de $89^{\circ}$. Resultados: Todos os pacientes foram submetidos ao tratamento cirúrgico com RCVP múltiplos níveis, com número médio de 3,6 vértebras ressecadas, média de tempo cirúrgico de 359 minutos, período médio de internação pós-operatória de 21,2 dias. O seguimento médio foi de 29 meses. A média de correção da cifose foi de 62,6\%. Antes da cirurgia, todos os pacientes tinham sinais de sofrimento medular, sendo que um deles não apresentava déficit de força ou sensibilidade (ASIA E), porém havia a presença de sinais piramidais e história de quedas. Os outros 4 possuíam algum grau de disfunção sensitivo-motora, com escore ASIA variando de A a D. Como complicações pós-operatórias ocorreram duas deiscências de sutura, um pneumotórax e uma pneumonia, todas com evolução favorável. Quatro pacientes evoluíram com melhora neurológica e um deles apresentou manutenção do déficit neurológico até o último seguimento. Conclusão: A RCVP múltiplos níveis se mostrou uma opção segura e eficaz no tratando da cifose na TB vertebral em crianças com déficit neurológico. Nível de evidência IV; Série de Casos.

Descritores: Tuberculose da Coluna Vertebral; Compressão da Medula Espinhal; Déficits Neurológicos.

\section{RESUMEN}

Objetivo: Evaluar los resultados clínicos y radiológicos de la vertebrectomía posterior en múltiples niveles en el tratamiento de la cifosis por tuberculosis vertebral en niños menores de 9 años con déficit neurológico. Métodos: Estudio retrospectivo de una serie de 5 casos, siendo 4 del sexo femenino 1 del sexo masculino, con promedio de edad de 4,7 años en el momento de la cirugía y múltiples niveles de tuberculosis espinal con cifosis promedio de 89 grados. Resultados: Todos los pacientes se sometieron a tratamiento quirúrgico por RPCV en niveles múltiples, con una media de 3,6 vértebras resecadas, tiempo operatorio promedio de 359 minutos y estancia promedio postoperatoria de 21,2 días. El seguimiento promedio fue de 29 meses. La corrección de la cifosis promedio fue del 62,6\%. Antes de la cirugía, todos los pacientes tenían signos de lesión de la médula espinal, uno de los cuales no tenía déficit de fuerza o sensibilidad (ASIA E), pero tenía signos piramidales y antecedentes de caídas. Los otros 4 tenían algún grado de disfunción sensoriomotora con puntuación de ASIA que variaba de A a D. Las complicaciones postoperatorias incluyeron dos dehiscencias de sutura, un neumotórax y una neumonía, todas con evolución favorable. Cuatro pacientes tuvieron mejoría neurológica y uno de ellos tuvo persistencia del déficit neurológico hasta el último seguimiento. Conclusiones: La RPCV ha demostrado ser una opción segura y eficaz en el tratamiento de la deformidad cifótica en la tuberculosis espinal en niños con déficit neurológico. Nivel de evidencia IV; Serie de Casos.

Descriptores: Tuberculosis de la Columna Vertebral; Compresión de la Médula Espinal; Disfunción Neurológica. 


\section{INTRODUCTION}

Tuberculosis (TB) is an infectious disease that has existed for millennia and remains a major global health problem. In 2015, the worldwide incidence of TB was estimated at 10.4 million cases. ${ }^{1} \mathrm{Ap}$ proximately $10 \%$ of patients with extra-pulmonary tuberculosis have skeletal involvement, the spine being the principal bone segment affected and responsible for around $50 \%$ of these cases, followed by the hip and the knee. ${ }^{2}$ Severe kyphosis can result from many conditions, including congenital deformities, post-laminectomy kyphosis, trauma, bone dysplasia, neurofibromatosis, and granulomatous diseases. ${ }^{3}$ Vertebral TB has become one of the main causes of severe kyphosis when neglected or treated late, especially in developing countries. ${ }^{4}$ Without treatment, progression to an esthetically significant deformity and neurological deficit are common outcomes. 5,6

The primary objectives of surgery in vertebral TB are drainage of the abscess with removal of the necrotic tissue, anterior decompression of the spinal cord, and stabilization of the spine and, secondarily, correction of the kyphotic deformity to prevent the development of paraplegia, as well as cosmetic improvement and improvement of lung function and of pain associated with the costo-pelvic impact. In cases of severe deformity, vertebrectomy is an appropriate technique that makes circumferential decompression and correction of kyphosis possible. ${ }^{7}$ In recent years, spine surgeons have increasingly adopted posterior vertebrectomy or posterior vertebral column resection (PVCR) in the surgical treatment of rigid spinal deformities. According to the Schwab classification of vertebral osteotomies, ${ }^{8}$ the multiple-level PVCR falls under type IV, which corresponds to osteotomies with a greater degree of complexity and should be used as the last resort in the correction of severe, rigid, and principally angular deformities. PVCR was first described by Suk et al. ${ }^{9}$, who demonstrated its advantages, such as shorter surgical time and fewer complications, as compared to long vertebral resection procedures involving a double anterior and posterior approach. The efficacy of this technique has also been shown in the surgical treatment of severe pediatric deformities. ${ }^{10,11}$ The objective of our study was to evaluate 5 patients under 9 years of age diagnosed with kyphosis secondary to TB and neurological deficit, who were treated using the multiple-level PVCR technique.

\section{METHODS}

This was a retrospective study of 5 patients with kyphosis from $\mathrm{TB}$, one male and 4 female, who underwent multiple-level PVCR surgical correction of the deformity. All patients had a confirmed histopathological diagnosis of tuberculous infection. The mean age of the patients at the time of surgery was 4.75 years (1.58 to 8.75 years). All patients had important segmental kyphosis with a mean angulation of $89^{\circ}\left(42^{\circ}\right.$ to $\left.110^{\circ}\right)$. The mean number of vertebral bodies impacted by the disease was 3.8 (2 to 5). Prior to surgery, all patients presented signs of medullary distress. One of them did not have any strength or sensitivity deficit (ASIA E), but presented pyramidal signs and a history of falls, while the other four had some degree of sensory-motor impairment, with ASIA scores ranging from A to D.

The study participants signed the Informed Consent Form. All patients underwent a serial neurological assessment and were evaluated according to signs of medullary distress, such as gait abnormalities, pyramidal signs, and sensory-motor function, the latter graded using the ASIA score. ${ }^{12}$ Panoramic anteroposterior and lateral spinal radiographs were taken preoperatively, postoperatively, and at all outpatient follow-up visits. The kyphosis angle was defined in the lateral radiograph as the angle between the upper plate of the first morphologically normal vertebra above the deformity and the lower plate of the first morphologically normal vertebra below the deformity. The measurements were taken using Surgimap ${ }^{\circledR}$ software. (Figure 1)

\section{Surgical technique}

With the patient under general anesthesia and multimodal neurophysiological monitoring, we positioned them in ventral decubitus on cushions on a radiotransparent table. A longitudinal median incision

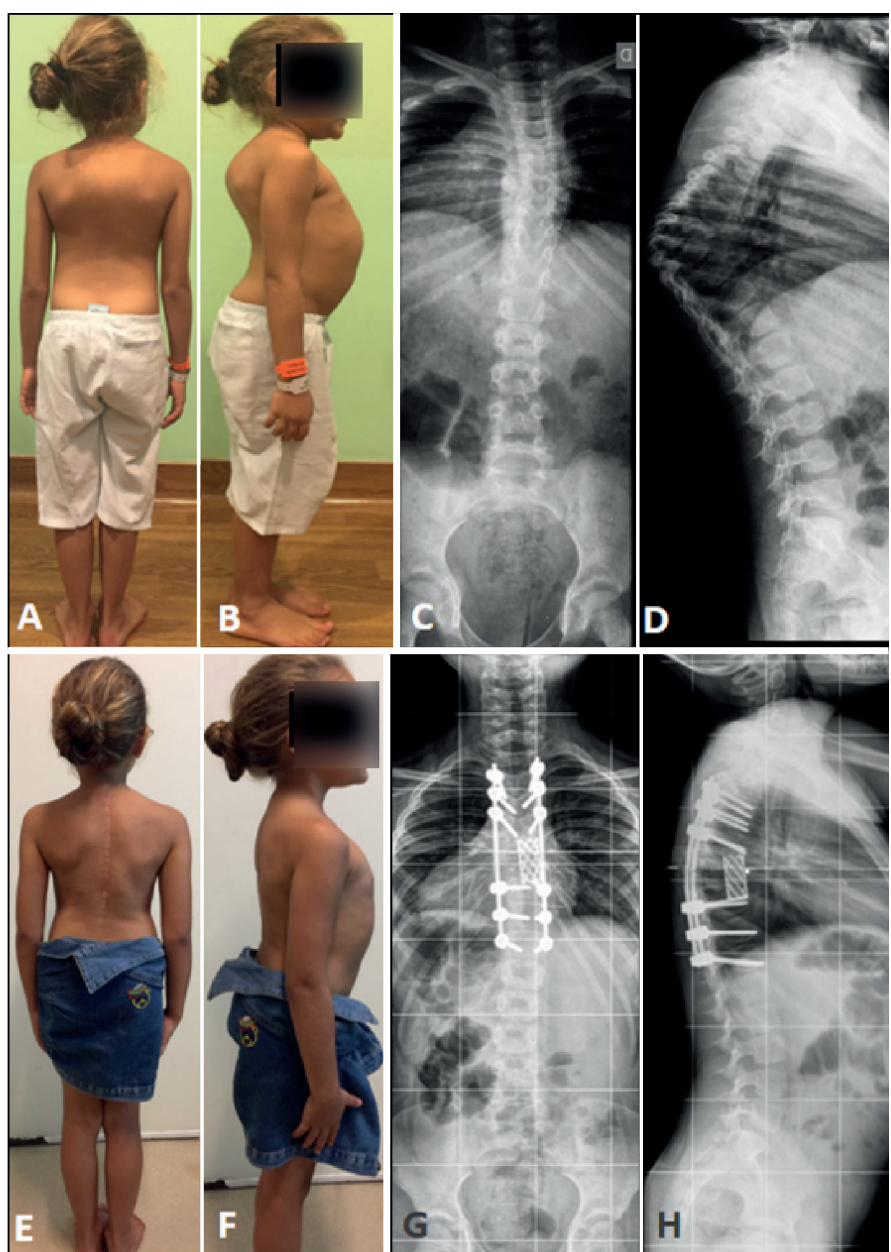

Figure 1. Illustration of Case 3: ( hild at 8 years and 9 months, strength and sensitivity preserved, but with the presence of pyramidal signs and a history of falls. Preoperative clinical photos ( $\mathrm{A}$ and $\mathrm{B}$ ) and panoramic radiographs ( $\mathrm{C}$ and D). Postoperative clinical photos ( $\mathrm{E}$ and $\mathrm{F})$ and panoramic radiographs ( $\mathrm{G}$ and $\mathrm{H})$.

was made over the planned instrumentation levels. Subperiosteal dissection with meticulous hemostasis was performed from medial to lateral and, at the level planned for the PVCR, the traverse process and the 3 or $4 \mathrm{~cm}$ of the medial part of the corresponding posterior rib were exposed. Facetectomies and bipedicular instrumentation of the levels to receive arthrodesis were performed, generally 2 to 3 levels above and below the PVCR. Because of the small size of the vertebrae and in order to avoid cutaneous complications, posterior cervical fixation implants with $3.5 \mathrm{~mm}$ screws and rods were used. A complete laminectomy and costo-transversectomy were performed at the levels to be resected, after fluoroscopic confirmation. Before we began the resection of the vertebral body, a temporary contralateral rod was placed as a support to prevent translocation or a possible iatrogenic lesion of the spinal cord. During this stage greater care had to also be taken to avoid the occurrence of pleural lesion. Subperiosteal dissection of the vertebral body was initiated and directed anteriorly from the lateral surfaces of this body. Malleable retractors were used to protect the pleura and the great vessels during this maneuver. During the dissection and exposure of the lateral wall of the vertebral body hemostasis had to be meticulous to prevent lesion of the segmental vessels. The vertebral body and the intervening discs were removed. To complete the resection, the temporary fixation rod was moved to the side and the remaining contralateral vertebral body was resected in the same way. Correction of the deformity was accomplished by modeling the rods in situ and by changing the temporary hypomodeled rods to the desired shape one by one. To prevent inadvertent distraction of the spinal cord and of the neural elements, the spine had to initially be 
shortened through light compression over the resected gap. After obtaining correction, the temporary rods were replaced one by one by the final rods to prevent loss of correction. The remaining anterior gap was filled with autologous bone graft contained inside a titanium cage (Figure 2). Anterior or circumferential arthrodesis at the level of the osteotomy and posterior fusion of all instrumented levels were performed. Following the placement of the posterior graft, the surgical wound was closed by planes and a suction drain installed.

\section{RESULTS}

The mean residual deformity in degrees after correction in the sagittal plane was $55.7^{\circ}\left(11^{\circ}\right.$ to $\left.78^{\circ}\right)$, with a mean correction rate of $62.6 \%$ (26.2 to $81.7 \%$ ). The mean procedural time was 359 minutes (270 to 530 minutes). The mean patient follow-up was 29 months (11 to 53 months). Complications occurred in three patients, including two cases of suture dehiscence, one of pneumothorax, and one case of pneumonia. (Figure 3) The mean postoperative hospitalization was 21.2 days (15 to 32 days). The patients' neurological examinations were recorded both preoperatively and during postsurgical follow-up. Four patients showed improvement according to the ASIA neurological scale and one of them continued with neurological deficit until the last follow-up visit. (Table 1) Computed tomography performed 6 months following surgery showed bone consolidation inside the titanium cage in all five patients. (Figure 4)

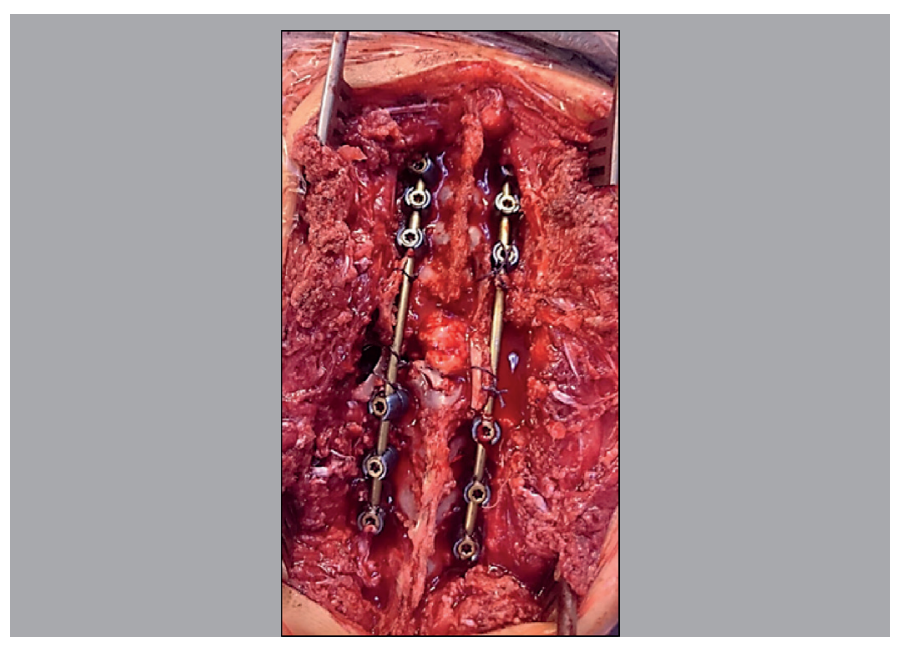

Figure 2. Intraoperative photos following arthrodesis and final correction. Note the circumferential medullary decompression and the ancillary rib graft for posterior reinforcement of the arthrodesis.

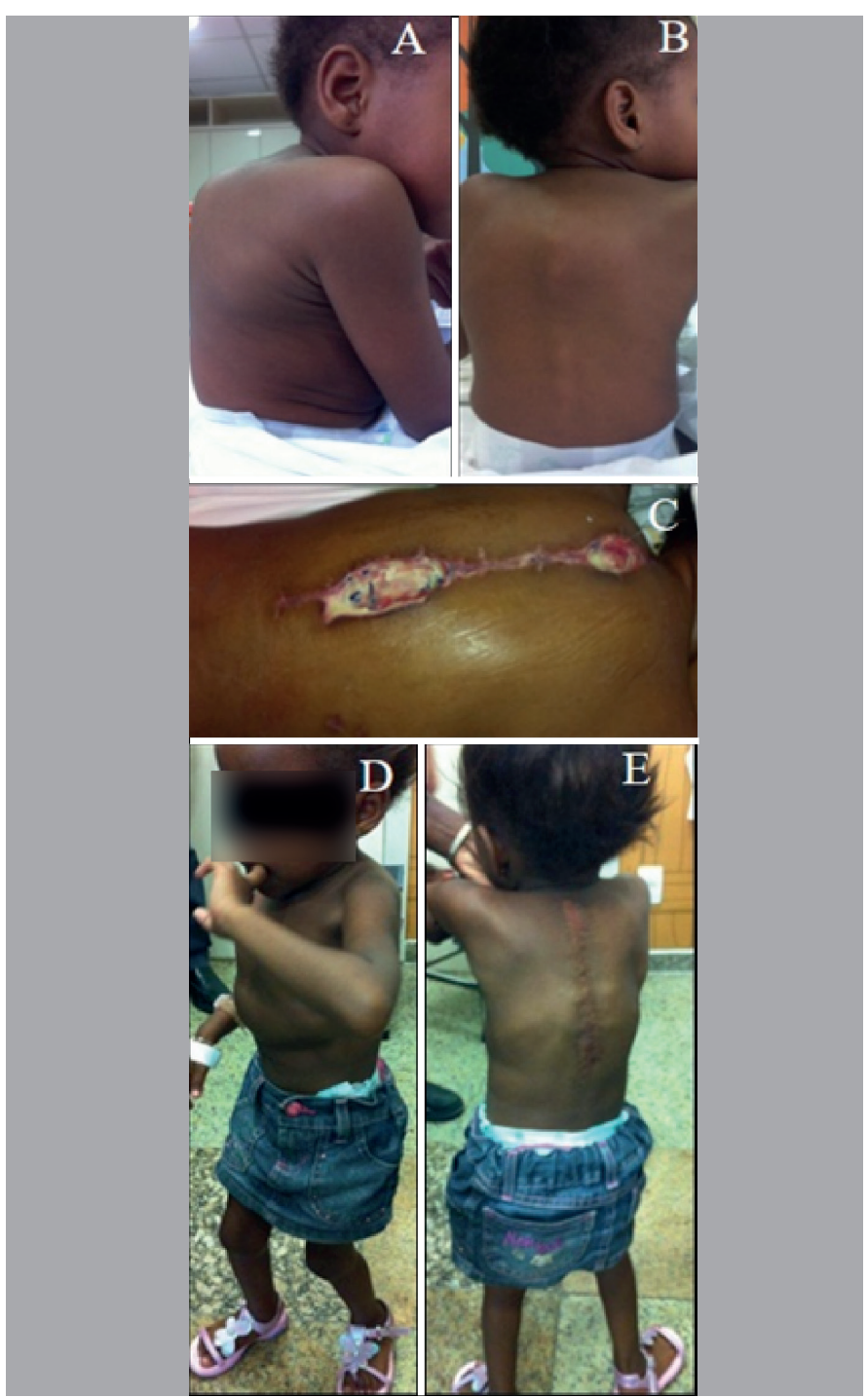

Figure 3. Illustration of Case 5: preoperative photos (A and B) showing the patient with significant thoracic kyphosis and unable to remain standing. Postoperative photo (C) showing the dehiscence of the sutures secondary to cutaneous necrosis $(C)$. Late postoperative photos ( $D$ and $E$ ) with the patient presenting improved motor function of the lower members, important clinical correction of kyphosis, and good healing of the surgical wound.

Table 1. Clinical and radiological results of the correction of kyphosis from TB by multiple-level PVCR in children.

\begin{tabular}{|c|c|c|c|c|c|c|c|c|c|}
\hline Case $\mathbf{N}^{\circ}$ & Age/Sex & $\begin{array}{l}\text { Follow-up } \\
\text { (months) }\end{array}$ & $\begin{array}{l}\text { Segment } \\
\text { affected }\end{array}$ & $\begin{array}{c}\text { Radiological signs } \\
\text { of spine at risk }\end{array}$ & $\begin{array}{c}\text { Surgical time } \\
\text { (minutes) }\end{array}$ & $\begin{array}{l}\text { Postoperative } \\
\text { hospitalization } \\
\text { time (days) }\end{array}$ & $\begin{array}{c}\text { Cobb } \\
\text { pre / post } \\
\text { Correction rate }\end{array}$ & $\begin{array}{c}\text { ASIA } \\
\text { pre/ post }\end{array}$ & $\begin{array}{l}\text { Fusion in } \mathrm{CT} \\
6 \mathrm{~m} \text { post-op }\end{array}$ \\
\hline 1 & $4 y 7 m / M$ & 28 & T7-T8 & 2 & $290 \mathrm{~min}$ & 15 & $\begin{array}{c}42^{\circ} / 31^{\circ} \\
26.2 \%\end{array}$ & $C / E$ & + \\
\hline 2 & $1 \mathrm{y} 7 \mathrm{~m} / \mathrm{F}$ & 11 & T3-T6 & 4 & $275 \mathrm{~min}$ & 32 & $\begin{array}{c}105^{\circ} / 27^{\circ} \\
74.3 \%\end{array}$ & $A / A$ & + \\
\hline 3 & $8 y 9 m$ / F & 10 & T5-T9 & 2 & $430 \mathrm{~min}$ & 19 & $\begin{array}{c}95^{\circ} / 42^{\circ} \\
56 \%\end{array}$ & $E / E$ & + \\
\hline 4 & $5 y 11 \mathrm{~m} / \mathrm{F}$ & 53 & T3-T6 & 4 & $530 \mathrm{~min}$ & 20 & $\begin{array}{c}110^{\circ} / 78^{\circ} \\
29 \%\end{array}$ & $C / D$ & + \\
\hline 5 & $2 \mathrm{y} 11 \mathrm{~m} / \mathrm{F}$ & 43 & T6-T9 & 3 & $270 \mathrm{~min}$ & 20 & $\begin{array}{c}93^{\circ} / 17^{\circ} \\
81.7 \%\end{array}$ & $B / E$ & + \\
\hline
\end{tabular}



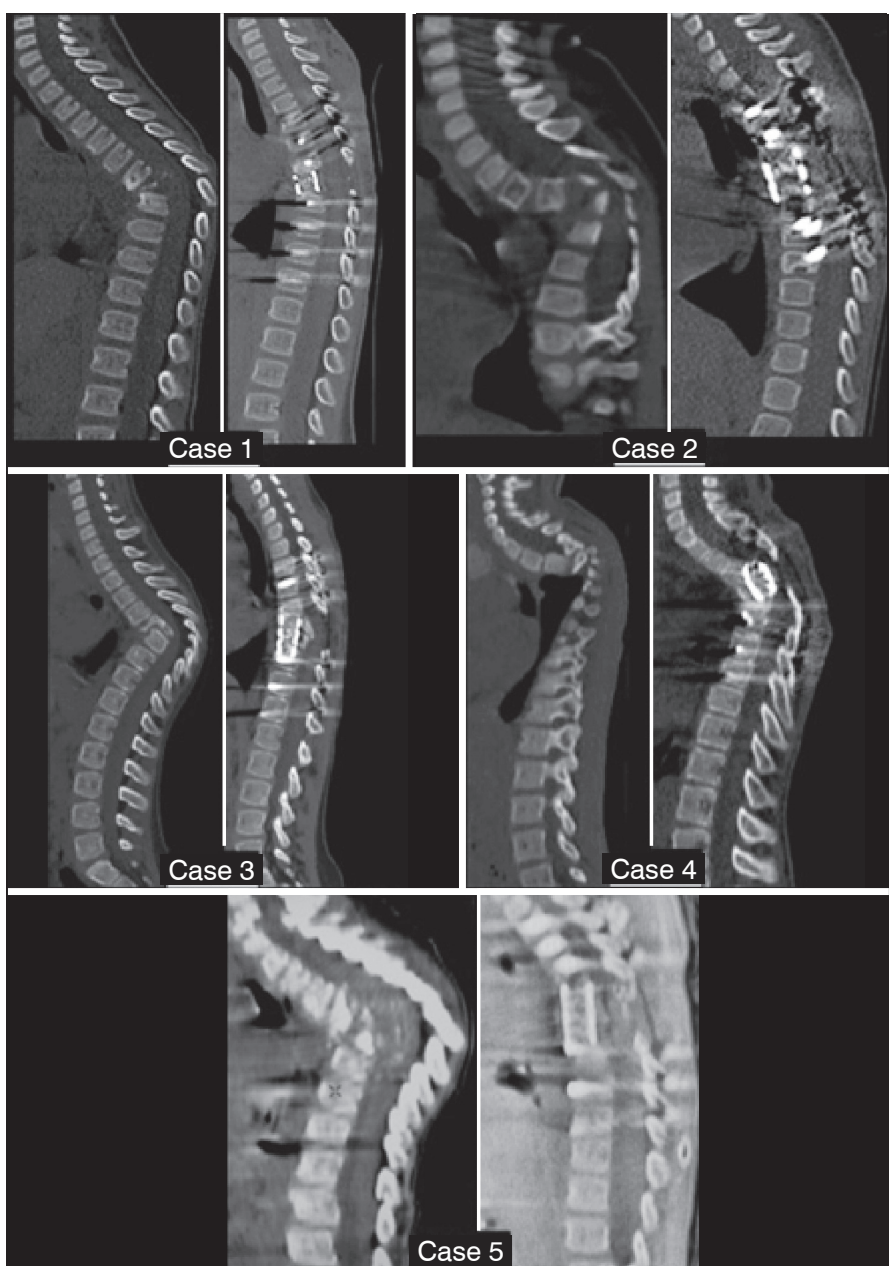

Figure 4. Sagittal CT reconstructions of all patients in the preoperative period and at 6 months following surgery, showing the bone consolidation of the arthrodesis.

\section{DISCUSSION}

Among the different causes of severe kyphotic deformity, spinal TB is quite common, mainly in developing countries. The infectious process in this pathology usually destroys the anterior and middle vertebral columns of the affected vertebrae, in addition to damaging the growth plates in the child, while the posterior columns continue to grow resulting in the development of kyphosis. When this kyphosis reaches high levels, it can lead to the occurrence of neurological damage and even paralysis, in addition to significant esthetic impact. ${ }^{13,14}$ Most cases of vertebral TB respond well to drug treatment and with the advent and availability of potent tuberculostatic drugs, surgical treatment is reserved for patients with neurological deficit, vertebral instability, and failed conservative treatment. ${ }^{1}$ The severity of the deformity in vertebral TB depends on the extent of bone destruction, the vertebral segment affected, and the age of the patient, the most serious deformities being seen in young children and in lesions involving the thoracic and thoracolumbar spines. In recent years, the instability criteria proposed by Rajasekaran have been used to assist in making a decision between clinical and surgical treatment, focused on preventing kyphosis and deficit. This author proposed the following radiological signs of a spine at risk: separation of the facet joints, posterior retropulsion of the diseased segment, lateral translation of the spine, and "toppling". Each of these signs adds 1 point, for a maximum total of 4 points. Patients less than 7 years of age, destruction of more than 2 vertebral bodies, and 2 or more radiological signs of instability are indicative of intervention surgery. ${ }^{15}$ In children, the deformity may continue to progress during growth, even after the infection is cured, making clinical and radiological follow-up necessary until skeletal maturity is reached. ${ }^{16}$

Traditionally, surgical treatment of vertebral TB is performed through decompression, debridement, and anterior approach mechanical support, and can be complemented by posterior arthrodesis. In the past, reestablishing mechanical support was achieved using structural grafts, generally from the fibula or rib. In recent decades, metallic implants offer biomechanical advantages and promote less adhesion of tuberculosis bacilli, ${ }^{17,18}$ making the use of metallic cages prefilled with autologous graft as support for anterior arthrodesis possible. Studies show that the anterior approach to the spine is associated with higher morbidity and greater impairment of postoperative pulmonary function. ${ }^{19,20}$ Using the PVCR technique, it is possible to achieve total circumferential decompression and flexibilization without incurring the morbidity associated with an anterior thoracotomy. Bumpass et al. ${ }^{21}$ reported that in pediatric patients PVCR results in a small but significant improvement in respiratory function tests, especially in those patients with greater lung and chest growth potential prior to surgery. We know that, despite excellent radiographic results, PVCR is a technically complex and challenging procedure associated with a high level of complications, at around $59 \%{ }^{22}$

There are few reports in the literature documenting multiple-level PVCR outcomes in children less than 9 years old, especially for vertebral TB. We consider the restricted number of cases, the lack of a control group, and the lack of longer postoperative follow-up to be limitations of our study. Fusion of the thoracic spine in young children can impair lung development and the final size of the thoracic cavity, and therefore is always of pertinent concern. ${ }^{23}$ Given the gravity the cases and the presence of already established neurological deficit in all our study patients, we opted for medullary decompression associated with posterior arthrodesis, involving at least two proximal and distal vertebral segments to provide sufficient stability for the osteotomy and achieve a spine without deformity or compression. We are aware of the possibility of future repercussions to the respiratory function of these children, but faced with this complex context, we opted to prioritize the resolution of the neurological deficit and the deformity.

\section{CONCLUSION}

Multiple-level PVCR was shown to be a safe and effective option in the treatment of kyphosis in young children with vertebral TB associated with neurological deficit.

All authors declare no potential conflict of interest related to this article.

CONTRIBUTION OF THE AUTHORS: Each author made significant individual contributions to the manuscript. AGCB (0000-0002-8337-7676)*, LECTS $(0000-0003-2631-5492)^{\star}$, MGSP $(0000-0002-5728-4273)^{\star}$, ALLB $(0000-0002-6517-4285)^{\star}$, and LRC $(0000-0002-7705-546 X)^{\star}$ participated actively in the discussion of the results and the review and approval of the final version of the article. ${ }^{*}$ ORCID (Open Researcher and Contributor ID).

\section{REFERENCES}

1. World Health Organization. Guidelines for treatment of tuberculosis [Internet]. Geneva: World Health Organization; 2016 [cited 2015 Jul 27]. Available from: http://www.who.int/ tb/publications/2010/9789241547833/en/.

2. Gautam MP, Karki P, Rijal S, Singh R. Pott 's spine and Pott's paraplegia. JNMA J Nepal Med Assoc. 2005;44(159):106 -15
3. Macagno AE, O'Brien MF. Thoracic and thoracolumbar kyphosis in adults. Spine (Phila Pa 1976). 2006;31(suppl 19):s161-70

4. Pappou IP, Papadopoulos EC, Swanson AN, Mermer MJ, Fantini GA, Urban MK, et al. Pott disease in the thoracolumbar spine with marked kyphosis and progressive paraplegia necessitating posterior vertebral column resection and anterior reconstruction with acage. Spine (Phila Pa 1976). 2006:31(4):E123-7. 
5. Smith-Peterson MN, Larsen CB, Aufranc OE. Osteotomy of the spine for correction of flexion deformity in rheumatoid arthritis. Clin Orthop Relat Res. 1969;66:6-9.

6. Schettino LC, Carelli LE, Barbosa MO. Tuberculose vertebral: análise descritiva de uma série de casos submetidos a tratamento cirúrgico. Coluna/Columna. 2010;9(2):119-25.

7. Boachie-Adjei O, Papadopoulos EC, Pellisé F, Cunningham ME, Perez-Grueso FS, Gupta M, et al. Late treatment of tuberculosis-associated kyphosis: literature review and experience from a SRS-GOP site. Eur Spine J. 2013;22 (Suppl 4):S641-6.

8. Schwab F, Blondel B, Chay E, Demakakors J, Lenke L, Tropiano P, et al. The comprehensive anatomical spinal osteotomy classification. Neurosurgery. $2014 ; 74(1): 112-20$

9. Suk SI, Kim JH, Kim WJ, Lee SM, Chung ER, Nah KH. Posterior vetebral column resection for severe spinal deformities. Spine (Phila Pa 1976). 2002;27(21):2374-82.

10. Lenke LG, O'Leary PT, Bridwell KH, Sides BA, Koester LA, Blanke KM. Posterior vertebra column resection for severe pediatric deformity: minimum two-year follow-up of thirty-five consecutive patients. Spine (Phila Pa 1976). 2009;34(20):2213-21.

11. Chang DG, Yang, JH, Lee JH, Kim JH, Suh SW, Kim YH, et al. Pediatric Posterio Vertebral Column Resectio (PVCR): Before and After Ten Years of Age. Greater Than 10-Year Follow-Up. Spine (Phila Pa 1976). 2016;41(21):1271-8.

12. American Spinal Injury Association. International standards for neurological classification of spine injury. Atlanta,GA: Author, 2008.

13. Rajasekaran S, Vijay K, Shetty AP. Single-stage closing-opening wedge osteotomy of spine to correct severe post-tubercular kyphotic deformities of the spine: a 3-year follow-up of 17 patients. Eur Spine J. 2010;19(4):583-92

14. Wang $Y$, Zhang $Y$, Zhang $X$, Huang $P$, Xiao S, Wang Z, et al. A single posterior approach for multilevel modified vertebral column resection in adults with severe rigid congenital kypho- scoliosis: a retrospective study of 13 cases. Eur Spine J. 2008;17(3):361-72.

15. Rajasekaran S. Buckling colapse of the spine in childhood spinal tuberculosis. Clin Ortho Relat Res. 2007:460:86-92.

16. Rajasekaran S. Natural history of Pott's kyphosis. Eur Spine J. 2013.;22(suppl 4):S634-40.

17. Ha KY, Chung YG, Ryoo SJ. Adherence and biofilm formation of Staphylococcus epidermidis and Mycobacterium tuberculosis on various spine implants. Spine (Phila Pa 1976). 2005;30(1):38-43.

18. Oga M, Arizono T, Takasita M, Sugioka Y. Evaluation of the risk of instrumentation as a foreign body in spinal tuberculosis. Spine (Phila Pa 1976). 1993;18(13):1890-4.

19. Newton PO, Perry A, Bastrom TP, Lenke LG, Betz RR, Clements D, et al. Predictors of change in postoperative pulmonary function in adolescent idiopathic scoliosis: a prospective study of 254 patients. Spine (Phila Pa 1976). 2007;32(17):1875-82.

20. Kim YJ, Lenke LG, Bridwell KH, Cheh G, Sides B, Whorton J. Prospective pulmonar function comparison of anterior spinal fusion in adolescent idiopathic scoliosis: thoracotomy versus thoracoabdominal approach. Spine (Phila Pa 1976). 2008;33(10):1055-60.

21. Bumpass DB, Lenke LG, Bridwell KH, Stallbaumer JJ, Kim YJ, Wallendorf MJ, et al. Pulmonary Function Improvement After Vertebral Column Ressection for Severe Spinal Deformity. Spine (Phila Pa 1976) 2014;39(7):587-95.

22. Lenke LG, Newton PO, Sucato DJ, Sufflebarger HL, Emans JB, Sponseller PD, et al. Complications after 147 consecutive vertebral column resections for severe pediatric spinal deformity: a multicenter analysis. Spine (Phila Pa 1976). 2013;38(2):119-32.

23. Goldberg CJ, Gillic I, Connaughton O, Moore DP, Fogarty EE, Canny GJ, et al. Respira tory Function and Cosmesis at Maturity inInfantile-onset Scoliosis. Spine (Phila Pa 1976). 2003:28(20):2397-406. 